\title{
The Nasolabial Fold as Potential Vascular Receptor Site: An Anatomic Study
}

\author{
Jeroen M. Smit, M.D., ${ }^{1}$ Pieter Q. Ruhe, M.D., Ph.D., 2 \\ Rafael Acosta, M.D., E.B.O.P.R.A.S., ${ }^{1}$ Jan G. Kooloos, M.D., Ph.D., 3 \\ and Ed H.M. Hartman, M.D., Ph.D.2
}

Free and pedicled flaps are frequently used in reconstruction of the lower twothirds of the face. For these reconstructions, the submandibular facial vessels are extensively used as a receptor site. In this anatomic study, we investigate if the facial vessels in the nasolabial fold can be used as a receptor site as well. In 13 human cadavers, the facial artery and vein were dissected in the nasolabial fold in the same way as would be done during surgery. The ease of dissection and length, diameter, and location of the vessels were analyzed. The average length of the dissected artery was $28 \mathrm{~mm}$ ( \pm 11 standard deviations $[\mathrm{SD}])$ and of the dissected vein, $19 \mathrm{~mm}( \pm 6 \mathrm{SD})$. The mean diameter of the artery was $1.5 \mathrm{~mm}( \pm 0.4 \mathrm{SD})$ and $2.5 \mathrm{~mm}( \pm 0.8 \mathrm{SD})$ for the vein. In $85 \%$ of the sides, both vessels were suitable to use as a microsurgical receptor site. The easy access and the measured diameter of the facial vessels in the nasolabial fold make it a potential site for microsurgical anastomosis.

KEYWORDS: Facial artery, receptor site, nasolabial fold, free flap, reconstruction

Large head and neck defects cause functional as well as aesthetic problems. Free and pedicled flaps are extensively used in the reconstruction of these defects. The type of flap can vary and depends on the size and location of the lesion. Radial forearm, fibula, rectus abdominis, and latissimus dorsi flaps are frequently used flaps in head and neck reconstructions. ${ }^{1-5}$ Smaller flaps based on the temporal artery, ${ }^{6}$ and pedicled flaps of the facial artery ${ }^{7-10}$ have been described as well.

As a recipient site in perioral and oral reconstructions, the facial artery and vein have been addressed frequently. Although the precise location of the anastomosis is seldom stated, the common site at which vessels are anastomosed to the facial artery and vein is the border of the mandible. ${ }^{11-13}$ Inspired by a report by Pribaz et al, ${ }^{14}$ we started using the facial vessels at the nasolabial fold as a microvascular receptor site in selected cases. ${ }^{15}$ We used this location in maxilla reconstructions with a free microvascular bone transfer. To further investigate the potential of this site, we conducted this anatomic study.

\section{MATERIALS AND METHODS}

In 13 fresh cadavers, the facial artery and vein were dissected between the nasal rim and the corner of the mouth. To make our results directly relevant for clinical practice, the vessels were dissected in the same way as
${ }^{1}$ Department of Plastic and Reconstructive Surgery, Uppsala University Hospital, Uppsala, Sweden; ${ }^{2}$ Department of Plastic and Reconstructive Surgery and ${ }^{3}$ Department of Anatomy, Radboud University Medical Center Nijmegen, Nijmegen, The Netherlands.

Address for correspondence and reprint requests: Rafael Acosta, M.D., Chief, Reconstructive Microsurgery, Department of Plastic and Reconstructive Surgery, Uppsala University Hospital, SE-751 85
Uppsala, Sweden (e-mail: Rafael.Acosta.Rojas@akademiska.se).

J Reconstr Microsurg 2009;25:539-544. Copyright (C) 2009 by Thieme Medical Publishers, Inc., 333 Seventh Avenue, New York, NY 10001, USA. Tel: +1(212) 584-4662.

Received: February 24, 2009. Accepted after revision: May 26, 2009. Published online: August 12, 2009.

DOI 10.1055/s-0029-1234025. ISSN 0743-684X. 
would be done in surgery. So the incision was made following the nasolabial fold, and care was taken to minimize damage to the surrounding tissue. During dissection, the location of the facial vessels in comparison with other anatomic structures was noted. The vessels were excised, marked, and directly frozen to $-20^{\circ} \mathrm{C}$ to be analyzed at a later time.

The length and circumference $(c)$ of the defrosted vessels were measured with the aid of a stereomicroscope (Leica MZ 12, Wetzlar, Germany) with a magnification of $10 \times$. The vessels were kept in physiological solution to prevent dehydration. After measuring the length of the vessels, a 1-mm-thick slice was taken distally to measure the circumference. The slice was opened using microscissors and measured to enable calculation of the nondilated diameter $(d)$ of the vessels $(d=c / \pi)$.

\section{RESULTS}

\section{Descriptive Macroscopy}

Twenty-six nasolabial folds in 13 fresh cadavers were dissected (Fig. 1). In one side, the facial vessels could not be located. In three sides, multiple small-caliber branches of the artery or vein were seen distal to the labial branches. Therefore, these branches were not further dissected. In the remaining 22 sides, the artery and vein could be dissected more distally.

In all 25 sides, the artery was located underneath the zygomaticus muscle. The zygomaticus and levator angularis oris were connected to form a broad muscle in three sides. The facial vein was found within Bichat's fat pad in 20 sides and was situated deeper, either besides or beneath Bichat, in three. The buccal fat pad could not be located in two sides.



Figure 1 After incision of the nasolabial fold, the facial artery and vein are dissected. Two red vessel loops were used to identify the facial artery at the distal and the proximal end of the dissection. A blue vessel loop identifies the facial vein.

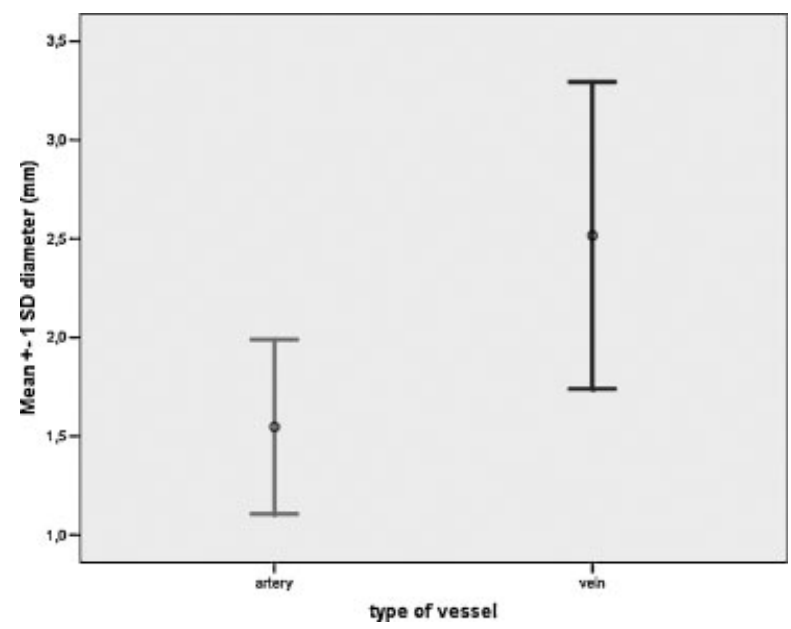

Figure 2 Mean diameter of facial vessels at the nasolabial fold. Error bars represent the mean and standard deviation.

\section{Length}

The mean length of the dissected artery was $28 \mathrm{~mm}$ ( \pm 11 standard deviations $[\mathrm{SD}])$ and of the dissected vein, $19 \mathrm{~mm}( \pm 6 \mathrm{SD})$.

\section{Diameter}

The mean diameter of the artery was $1.5 \mathrm{~mm}( \pm 0.4 \mathrm{SD})$ and of the vein, $2.5 \mathrm{~mm}( \pm 0.8 \mathrm{SD}$; Fig. 2$)$. In three sides, the arterial or venous diameter was below $1.0 \mathrm{~mm}$, making it unsuitable for a microvascular anastomosis.

\section{Feasibility as Receptor Side}

Of the 26 sides that were dissected, 22 (85\%) had an artery as well as a vein suitable to perform anastomosis. In two sides, the artery was of insufficient caliber to perform an anastomosis: in one side, the size of the vein was the limiting factor, and in the remaining side, neither the artery nor the vein could be located.

\section{DISCUSSION}

Flaps should be considered in perioral and oral defects if primary closure or closure by skin graft cannot be obtained. Free flaps are often used in larger perioral and oral defects that are too large for a pedicled flap. ${ }^{1}$ However, in smaller perioral and oral defects, free flaps can be used as well-for example, a radial forearm flap for cheek and mucosal defects, ${ }^{16,17}$ an iliac bone graft in maxilla reconstructions, ${ }^{18}$ and a cutaneous temporalis flap for upper lip and cheek reconstructions. ${ }^{6,19,20}$ Free flaps can also be used in nasal reconstructions. ${ }^{14}$

We investigated the possibilities for using the facial artery and vein in the nasolabial fold as a receptor site in free flap reconstructions by examination of the course, length, and diameter of the facial vessels at this 


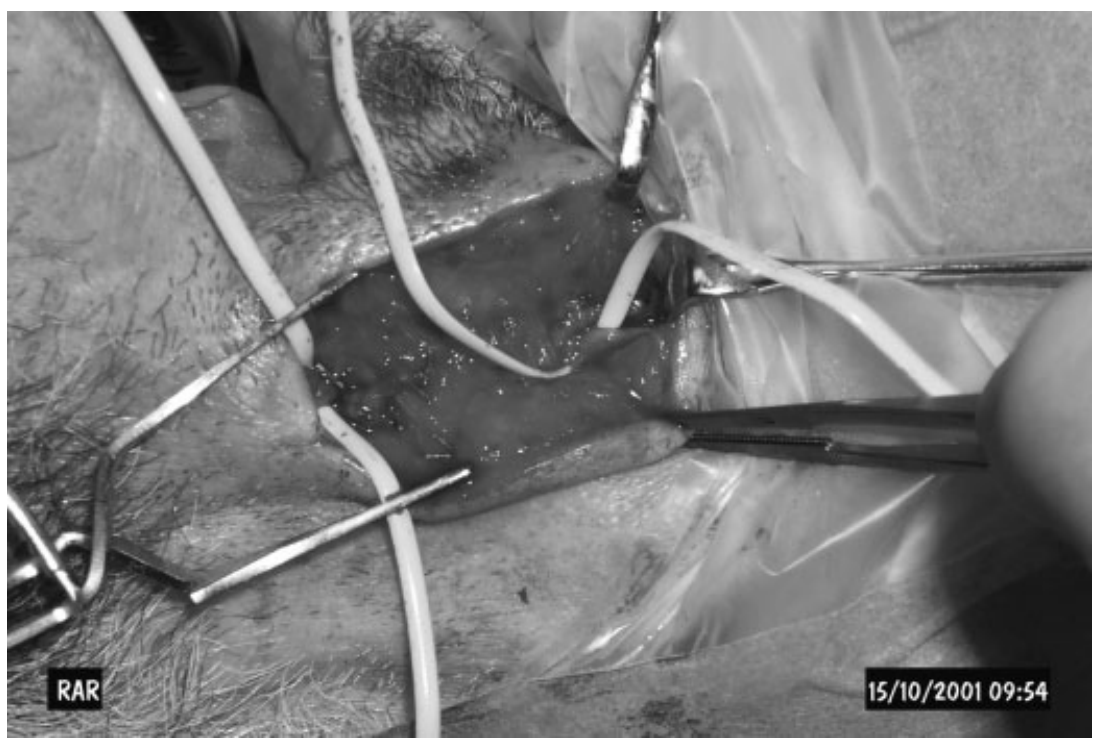

Figure 3 Clinical case in which the facial vessels were used as receptor site to reconstruct the maxilla with a vascularized humeral bone graft. The left vessel loop identifies the artery, the right vessel loop the vein. Further dissection was possible; however, the lengths of the artery and vein were sufficient to bring them superficial and perform the anastomosis.

site. The mean length of the dissected artery and vein was $28 \mathrm{~mm}( \pm 11 \mathrm{SD})$ and $19 \mathrm{~mm}( \pm 6 \mathrm{SD})$, respectively. The difference in length between the artery and vein was caused by their location. Because the artery was located more superficially, it was easier to dissect and could be dissected distally until the diameter was no longer fit for a reliable anastomosis. The vein, however, was situated in a deeper layer and, because of this, was only dissected until its length was sufficient to bring it superficial. This was done to minimize damage to the surrounding tissue. In the cases in which the length of the vein was not sufficient, the overlying zygomaticus muscle could be further divided to ensure a further dissection of the vein.

In the dissection of the vessels, different branching patterns were seen. These differences within the population and the overall differences in facial length resulted in the wide range in length of the studied vessels. Other reports confirm the broad variety in branching of the facial vessels. ${ }^{21-23}$

Compared with the clinical cases, which were our initial motivation to perform this anatomic study, the results of this study confirmed the potential of the nasolabial fold as a receptor site. In the clinical cases, however, the anatomic structures that overlay the vessels could be more easily mobilized, which further increases the accessibility of the vein. Also, the size of the artery and vein appeared larger in the clinical cases; however, no measurements were performed to verify this. Apart from this, the results of the anatomic dissection were about equal to the clinical cases (Fig. 3).

In their anatomic study, Zhao et al found an average arterial diameter of $1.9 \mathrm{~mm}( \pm 0.4 \mathrm{SD})$ and a venous diameter of $2.1 \mathrm{~mm}( \pm 0.4 \mathrm{SD}) .{ }^{24}$ Nishihara et al found a venous diameter of $2.0 \mathrm{~mm}( \pm 0.1 \mathrm{SD}) .{ }^{25}$ These results are similar to our results, although the variation of the venous diameter in our group is larger. An explanation for this difference can be our population size, which was about half of that in the study of Nishihara et al. The difference in arterial diameter measured in our study and in the study of Zhao et al might be explained by the research protocol. They investigated the diameter in living persons with a color Doppler ultrasonic system. We dissected the vessels in cadavers and cut them open to measure the diameter.

The facial vessels in the nasolabial fold offer microsurgeons a potential receptor site in the central facial region. One advantage it offers compared the conventional submandibular site is the use of a shorter pedicle. Also, the potential hazard of compression of the anastomosis in the submandibular area by forward flexion of the neck can be avoided by choosing a more distal anastomosis site. Other advantages of this site we have encountered during our clinical practice are summarized in Table $1 .^{15}$

\section{Table 1 Advantages of the Nasolabial Fold as an Anastomosis Site ${ }^{15}$}

Use of a shorter pedicle

Easy access to artery and vein

Superficial anastomosis

Potentially less compression in anastomotic area

Freedom of movement for the patient in relation to neck movements

Cosmetically acceptable scar, especially in the elderly 
Table 2 Potential Flaps to Be Anastomosed in the Nasolabial Fold and Their Diameters

\begin{tabular}{|c|c|c|}
\hline Type of Flaps & $\begin{array}{l}\text { Arterial } \\
\text { Diameter } \\
(\mathrm{mm})\end{array}$ & $\begin{array}{l}\text { Venous } \\
\text { Diameter } \\
(\mathrm{mm})\end{array}$ \\
\hline \multicolumn{3}{|l|}{ Bone flaps } \\
\hline Iliac crest ${ }^{28}$ & 1.7 & 2.1 \\
\hline Humeral bone $e^{29}$ & 1.8 & - \\
\hline Radial forearm bone ${ }^{16}$ & 2.46 & 2.53 \\
\hline \multicolumn{3}{|l|}{ Fasciocutaneous flaps } \\
\hline Radial forearm ${ }^{16}$ & 2.46 & 2.53 \\
\hline Lateral $\mathrm{arm}^{29}$ & 1.8 & - \\
\hline Anterolateral thigh ${ }^{30}$ & 1.0 & - \\
\hline Temporal skin ${ }^{31}$ & 2.14 & - \\
\hline Frontal branch & 1.61 & - \\
\hline Temporal branch & 1.68 & - \\
\hline Thoracodorsal artery perforator ${ }^{32}$ & 0.9 & - \\
\hline
\end{tabular}

We have summarized the suitable bone and fasciocutaneous flaps in this area that potentially could be used as free flaps (Table 2). These flaps offer vessel diameters that can be considered as compatible with the facial vessels in the nasolabial fold. Their diameters will allow an end-to-end anastomosis in most cases; if not, a sleeve anastomosis can be used. ${ }^{26,27}$

\section{CONCLUSION}

The diameters of both the facial artery and vein in the nasolabial fold make them a potential site for microsurgical anastomosis. The vessels can be easily dissected and placed beside each other at surface level, which makes performing microsurgical anastomoses easy and comfortable.

\section{NOTES}

Presented at the Summer Scientific Meeting of the British Association of Plastic, Reconstructive, and Aesthetic Surgeons, Deauville, France, July 4, 2007, and at the Spring Scientific Meeting of the Dutch Association of Plastic Surgeons, Utrecht, The Netherlands, April 5, 2007.

\section{REFERENCES}

1. Nakatsuka T, Harii K, Asato $\mathrm{H}$, et al. Analytic review of 2372 free flap transfers for head and neck reconstruction following cancer resection. J Reconstr Microsurg 2003;19: 363-368; discussion 369

2. Haughey $\mathrm{BH}$, Wilson E, Kluwe L, et al. Free flap reconstruction of the head and neck: analysis of 241 cases. Otolaryngol Head Neck Surg 2001;125:10-17

3. Nahabedian MY, Singh N, Deune EG, Silverman R, Tufaro AP. Recipient vessel analysis for microvascular reconstruction of the head and neck. Ann Plast Surg 2004;52:148-155; discussion 156-157

4. Urken ML, Weinberg H, Buchbinder D, et al. Microvascular free flaps in head and neck reconstruction. Report of 200 cases and review of complications. Arch Otolaryngol Head Neck Surg 1994;120:633-640

5. Soutar DS, Scheker LR, Tanner NS, McGregor IA. The radial forearm flap: a versatile method for intra-oral reconstruction. Br J Plast Surg 1983;36:1-8

6. Ozdemir R, Sungur N, Sensöz O, et al. Reconstruction of facial defects with superficial temporal artery island flaps: a donor site with various alternatives. Plast Reconstr Surg 2002;109:1528-1535

7. Pribaz JJ, Meara JG, Wright S, Smith JD, Stephens W, Breuing KH. Lip and vermilion reconstruction with the facial artery musculomucosal flap. Plast Reconstr Surg 2000;105: 864-872

8. Park C, Lineaweaver WC, Buncke HJ. New perioral arterial flaps: anatomic study and clinical application. Plast Reconstr Surg 1994;94:268-276

9. Hofer SO, Posch NA, Smit X. The facial artery perforator flap for reconstruction of perioral defects. Plast Reconstr Surg 2005;115:996-1003; discussion 1004-1005

10. Piggot TA, Logan AM, Knight SL, Milner RH. The facial artery island flap. Ann Plast Surg 1987;19:260-265

11. Zuker RM, Goldberg CS, Manktelow RT. Facial animation in children with Möbius syndrome after segmental gracilis muscle transplant. Plast Reconstr Surg 2000;106:1-8; discussion 9

12. Kumar PA, Hassan KM. Cross-face nerve graft with freemuscle transfer for reanimation of the paralyzed face: a comparative study of the single-stage and two-stage procedures. Plast Reconstr Surg 2002;109:451-462; discussion 463-464

13. Itoh Y, Arai K. Nasal reconstruction with a thin, free flap prefabricated with a silicone sheet: case report. J Reconstr Microsurg 1992;8:359-362

14. Pribaz JJ, Falco N. Nasal reconstruction with auricular microvascular transplant. Ann Plast Surg 1993;31:289297

15. Smit JM, Hartman EHM, Acosta R. Clinical experience with the nasolabial fold as receptor site in microvascular reconstruction. Microsurgery 2007;27:608-611

16. Savant DN, Patel SG, Deshmukh SP, Gujarati R, Bhathena HM, Kavarana NM. Folded free radial forearm flap for reconstruction of full-thickness defects of the cheek. Head Neck 1995;17:293-296

17. Duflo S, Lief F, Paris J, Giovanni A, Thibeault S, Zanaret M. Microvascular radial forearm fasciocutaneous free flap in hard palate reconstruction. Eur J Surg Oncol 2005;31:784791

18. Clayman L. Implant reconstruction of the bone-grafted maxilla: review of the literature and presentation of 8 cases. J Oral Maxillofac Surg 2006;64:674-682

19. Chang KP, Lai CS, Tsai CC, Lin TM, Lin SD. Total upper lip reconstruction with a free temporal scalp flap: long-term follow-up. Head Neck 2003;25:602-605

20. Lyons GB, Milroy BC, Lendvay PG, Teston LM. Upper lip reconstruction: use of the free superficial temporal artery hair-bearing flap. Br J Plast Surg 1989;42:333-336

21. Nagase T, Kobayashi S, Sekiya S, Ohmori K. Anatomic evaluation of the facial artery and vein using color Doppler ultrasonography. Ann Plast Surg 1997;39:64-67 
22. Koh KS, Kim HJ, Oh CS, Chung IH. Branching patterns and symmetry of the course of the facial artery in Koreans. Int J Oral Maxillofac Surg 2003;32:414-418

23. Nakajima H, Imanishi N, Aiso S. Facial artery in the upper lip and nose: anatomy and a clinical application. Plast Reconstr Surg 2002;109:855-861; discussion 862-863

24. Zhao Z, Li S, Xu J, et al. Color Doppler flow imaging of the facial artery and vein. Plast Reconstr Surg 2000;106:12491253

25. Nishihara J, Takeuchi Y, Miki T, Itoh M, Nagahata S. Anatomical study on valves of human facial veins. J Craniomaxillofac Surg 1995;23:182-186

26. de la Peña-Salcedo JA, López-Monjardin H. Sleeve anastomosis in head and neck reconstruction. Microsurgery 2000;20:193-194

27. Kanaujia RR, Hoi KI, Miyamoto Y, Ikuta Y, Tsuge K. Further technical considerations of the sleeve microanastomosis. Plast Reconstr Surg 1988;81:725-734
28. Shimizu T, Ohno K, Matsuura M, Segawa K, Michi K. An anatomical study of vascularized iliac bone grafts for dental implantation. J Craniomaxillofac Surg 2002;30:184188

29. Gehrking E, Remmert S, Majocco A. [Topographic and anatomic study of lateral upper arm transplants]. Ann Anat 1998;180:275-280

30. Nojima K, Brown SA, Acikel C, et al. Defining vascular supply and territory of thinned perforator flaps: part I. Anterolateral thigh perforator flap. Plast Reconstr Surg 2005;116:182-193

31. Chen TH, Chen CH, Shyu JF, Wu CW, Lui WY, Liu JC. Distribution of the superficial temporal artery in the Chinese adult. Plast Reconstr Surg 1999;104:1276-1279

32. Thomas BP, Geddes CR, Tang M, Williams J, Morris SF. The vascular basis of the thoracodorsal artery perforator flap. Plast Reconstr Surg 2005;116:818-822 